\title{
ISOLASI DAN MOLECULAR DOCKING SENYAWA 6,7-DIHIDRO-17- HIDROKSIERISOTRIN DARI DAUN DADAP BELENDUNG (Erythrina poeppigiana) TERHADAP AKTIVITAS SITOTOKSIK ANTIKANKER PAYUDARA MCF-7
}

\author{
Richa Mardianingrum $^{\mathrm{a}^{*}}$, Tati Herlina ${ }^{\mathrm{b}} \&$ Unang Supratman $^{\mathrm{b}}$ \\ ${ }^{\text {a }}$ STIkes Bakti Tunas Husada, Jl. Cilolohan 36 Tasikmalaya, Jawa Barat, 46115 \\ b Jurusan Kimia, Fakultas Matematika dan Ilmu Pengetahuan Alam, Universitas Padjadjaran, Jatinangor, \\ Sumedang, Jawa Barat, 45363 \\ * Alamat korespodensi : richa_ningrum@yahoo.com
}

\begin{abstract}
Abstrak: Erythrina (Leguminose) memiliki jumlah alkaloid paling banyak jika dibandingkan dengan senyawa metabolit sekunder lainnya, sehingga tumbuhan Erythrina dikenal dengan sebutan alkaloid eritrina. Erythrina yang paling banyak tumbuh di Indonesia adalah E. poeppigiana. Tujuan penelitian ini adalah untuk mengungkapkan senyawa aktif antikanker payudara MCF-7 secara in silico yang terdapat di dalam daun E. poeppigiana. Alkaloid dipisahkan dan dimurnikan melalui tahapan ekstraksi, fraksinasi, pemisahanan dan pemurnian yang dipandu dengan uji Dragendorff, senyawa alkaloid yang diperoleh diuji antikanker secara in silico terhadap reseptor EGFR2 yang bekerja pada sel kanker payudara MCF-7 menggunakan program ArgusLab dengan pembanding canertinib dan parameter yang diukur adalah energi bebas Gibbs ikatan $(\Delta \mathrm{G})$ dan konstanta inhibisi (Ki). Hasil dari penelitian ini diperoleh senyawa alkaloid golongan isokuinolin yakni 6,7dihidro-17-hidroksierisotrin. Senyawa 6,7-dihidro-17-hidroksierisotrin diprediksi mempunyai aktivitas sitotoksik terhadap sel kanker payudara MCF-7 dengan nilai $\Delta \mathrm{G}$ (Kcal/mol) dan $\mathrm{Ki}(\mathrm{nM})$ masing-masing sebesar $-8,11457$ dan $1,12.10^{-6}$. Sehingga dapat disimpulkan bahwa tumbuhan E. poeppigiana mempunyai potensi sebagai bahan dasar obat herbal antikanker payudara.
\end{abstract}

Kata kunci: Alkaloid, Erythrina, E. poeppigiana, sel kanker payudara MCF-7, in silico

Abstract: Erythrina (leguminose) has the most number of alkaloids when compared with other secondary metabolites, so Erythrina plants known as eritrina alkaloid. Erythrina, most widely grown in Indonesia is E. poeppigiana. The purpose of this study is to reveal the active anticancer compound MCF-7 breast in silico contained in the leaves of E. poeppigiana. Alkaloids are separated and purified through the stages of extraction, fractionation, and purification guided by Dragendorff test, alkaloid was tested as anticancer in silico to EGFR 2 working on breast cancer MCF-7 cell line using the ArgusLab program by canertinib as comparison and the measured parameters is the binding Gibbs free energy $(\Delta G)$ and the inhibition constants (Ki). The results of this study were obtained alkaloid class of isokuinolin namely 6,7-dihydro-17-hidroksierisotrin. The compound 6,7dihydro-17-hidroksierisotrin predicted to have a cytotoxic activity against breast cancer MCF-7 cell line with $\Delta G$ value (Kcal / mol) and Ki (nM) of (-8.11457; 1,12.10 $\left.{ }^{-6}\right)$. It was concluded that E. poeppigiana plants have potential as anticancer herbal medicine base material of the breast.

Keywords: Alkaloids, Erythrina, E. poeppigiana, MCF-7 breast cancer, in silico

\section{PENDAHULUAN}

Kanker merupakan penyakit yang menempati peringkat kedua sebagai penye-bab kematian. Hal ini menyebabkan pengembangan penelitian untuk menemukan obat-obat baru terus dikembangkan, bahkan dari bahan alam (Radji dkk, 2004). Kasus penyakit kanker di Indonesia dari tahun ke tahun terus meningkat dan kanker merupakan salah satu penyebab utama kematian. Obat kanker umumnya merupakan obat sintetis dengan harga relatif mahal dan memiliki efek samping yang cukup besar sehingga masyarakat banyak berpaling pada pengobatan tradisional.

Tumbuhan Erythrina poeppigiana dikenal dengan nama lokal "dadap belendung" famili Leguminosae merupakan tumbuhan obat untuk rematik, infeksi, batuk, demam, radang, dan obat cacing (Hanum \& Maesan, 1997)
Alkaloid dari ekstrak metanol kulit batang $E$. poeppigiana, telah berhasil diisolasi dan diperoleh dua golongan isokuinolin (Herlina et al., 2003), $\alpha$ eritroidin, $\beta$-eritroidin, 8 -okso- $\alpha$-eritrodin, 8 -okso- $\beta$ eritrodin (Djiogue et al., 2014), namun belum ditemukan senyawa alkaloid yang terdapat pada bagian daun yang beraktivitas sitotoksik terhadap sel kanker payudara MCF-7.

Pada pengujian aktivitas sitotoksik terhadap sel kanker payudara MCF-7, dilakukan dengan metode in silico secara molecular docking yang dapat memprediksi interaksi senyawa dengan reseptor. Dalam hal ini Epidermal Growth Factor Receptor 2 (EGFR 2) merupakan reseptor yang bekerja pada sel kanker payudara MCF-7.

Tujuan dari penelitian ini adalah untuk mengisolasi alkaloid dari daun E. poeppigiana dan uji aktivitas sitotoksik yang mekanisme kerjanya menghambat EGFR 2 pada sel kanker payudara 
MCF-7 dengan metode in silico secara molecular docking.

\section{BAHAN DAN METODE Bahan}

Sampel yang digunakan dalam penelitian ini adalah bagian daun E. poeppigiana yang diperoleh dari Ciater Subang, Provinsi Jawa Barat pada September 2014. Tumbuhan ini dideterminasi di Herbarium Departemen Biologi Universitas Padjadjaran.

Bahan kimia yang digunakan terdiri dari metanol, asam klorida $1 \%$, asam sulfat $2 \mathrm{~N}$, diklorometana, ammonium hidroksida, pereaksi Dragendorff dan Mayer. Silika Merck $\mathrm{G}_{60} \mathrm{GF}_{254}$, silika Merck $\mathrm{G}_{60}$ (70-230 mesh), analisis kromatografi lapis tipis (KLT) pada plat berlapis silika gel Merck $\mathrm{G}_{60} \mathrm{GF}_{254}$, asam sulfat $10 \%$ dalam etanol.

\section{Ekstraksi dan Isolasi}

Serbuk daun E.poeppigiana $(2,60 \mathrm{~kg})$ diekstraksi dengan metanol dengan teknik maserasi, diperoleh ekstrak metanol pekat $(195,19$ g). Ekstrak metanol pekat selanjutnya dilarutkan dalam air, kemudian diaasamkan dengan asam klorida $1 \%$ hingga $\mathrm{pH} 2-3$, lalu dipartisi dengan diklorometana, diperoleh fraksi diklorometana dan fraksi air asam, keduanya dipandu dengan uji Dragendorff. Kemudian fraksi air asam ditambahkan basa ammonium hidroksida hingga $\mathrm{pH}$ 9-10, dipartisi dengan diklorometana, diperoleh fraksi air basa dan fraksi diklorometana basa keduanya dipandu dengan uji Dragendorff. Fraksi diklorometana basa dipekatkan dan diperoleh fraksi pekat diklorometana sebanyak 2,21 g. Selanjutnya fraksi pekat diklorometana dipisahkan menggunakan kromatografi kolom dengan silika gel $\mathrm{G}_{60}$ dan eluen kloroform: metanol (98:2) secara isokratik, diperoleh sepuluh fraksi (FA-J). Fraksi FI (534,9 mg) dipisahkan dengan kromatografi kolom silika gel $\mathrm{G}_{60}$ dan eluen diklorometana:kloroform:methanol (1:0,9:0,1) diperoleh senyawa murni $(\mathbf{2 , 8} \mathbf{~ m g})$.

\section{Docking Senyawa}

\section{Preparasi Ligan}

Ligan digambar dalam bentuk 2D menggunakan software MarvinSketch 5.2 kemudian dilakukan optimasi geometri pada ligan, dengan protonasi $\mathrm{pH}$ 7,4 setelah itu save dalam bentuk .mrv. Lakukan Conformational search untuk penentuan konformasi struktur dan save as file dalam bentuk pdb dan mol2 (Purnomo, 2013).

\section{Validasi Metode Docking}

Program ArgusLab divalidasi untuk mendapat metode yang dapat dipercaya. Reseptor yang digunakan adalah reseptor-reseptor tuberkulosis yang didapat dari Protein Data Bank (PDB). Metode docking dikatakan baik jika nilai RMSD yang dihasilkan lebih kecil atau sama dengan 2 (Kartasasmita, 2009).

\section{Docking Menggunakan ArgusDock}

Docking senyawa dengan epidermal growth factor receptor 2 (EGFR 2) menggunakan sofware ArgusLab, dilakukan juga untuk canertinib sebagai pembanding. Pada proses docking gunakan grid box tiap reseptor yang sudah valid pada proses validasi sebelumnya.

\section{HASIL DAN PEMBAHASAN}

Dari hasil isolasi yang dilakukan pada daun E.poeppigiana dapat dihasilkan senyawa (Gambar 1) dengan hasil karakterisasi sebagai berikut:

Senyawa 6,7-dihidro-17-hidroksierisotrin Serbuk kuning. LC-MS [M-H] $]^{-} m / z \quad 330,44$, perhitungan senyawa adalah 331,45 sebagai $\mathrm{C}_{19} \mathrm{H}_{25} \mathrm{NO}_{4}$. IR (KBr) $\mathrm{V}_{\text {maks }} \mathrm{cm}^{-1} 3430,9 ; 2925,6 ; 1630,5$; dan 383,0. ${ }^{1} \mathrm{H}-$ NMR $\left(\mathrm{CD}_{3} \mathrm{OD}, 500 \mathrm{MHz}\right) \delta_{\mathrm{H}}(\mathrm{ppm}) 7,05(1 \mathrm{H}, d$, $J=5, \mathrm{H}-1), 6,80$ (1H, $d, J=5, \mathrm{H}-2), 3,97$ (1H, $m, \mathrm{H}-3)$, 2,72 (2H, $m, \mathrm{H}-4), 2,94(1 \mathrm{H}, m, \mathrm{H}-6), 2,63(1 \mathrm{H}, d$, $J=15, \mathrm{H}-7)), 2,55(1 \mathrm{H}, d, J=15, \mathrm{H}-7), 3,57(2 \mathrm{H}, m, \mathrm{H}-$ 8), 2,83 (2H, $m, \mathrm{H}-10), 4,16$ (2H, m, H-11), 8,55 (1H, s, H-14), 3,58 (3H, s, 15- $\left.\mathrm{OCH}_{3}\right), 3,83(3 \mathrm{H}, \mathrm{s}, 16-$ $\left.\mathrm{OCH}_{3}\right), 3,38\left(3 \mathrm{H}, \mathrm{s}, 3-\mathrm{OCH}_{3}\right), 3,23(1 \mathrm{H}, \mathrm{s}, 17-\mathrm{OH})$.<smiles></smiles>

Gambar 1. Struktur senyawa (6,7-dihidro-17hidroksierisotrin)

\section{Docking Senyawa Hasil Isolasi}

Metode docking yang digunakan yaitu program Arguslab. Pada program ArgusLab reseptor harus ditambahkan hidrogen terlebih dahulu, karena reseptor pada pdb belum memiliki ikatan hidrogen. Pada program ArgusLab harus dilakukan validasi metode docking tujuannya untuk mendapatkan metode yang baik. Syarat dikatakan metode yang digunakan itu baik atau valid memiliki nilai RMSD (Root Mean Square Deviation) < 2. Ligan asli 3W32 serta ligan copy di-dockingkan dengan reseptor EGFR 2 menggunakan metode ArgusDock didapat nilai RMSD 1,917605 $\AA$ menggunakan grid box $\mathrm{X}=20,75, \mathrm{Y}=14,25$ dan $\mathrm{Z}=17,25$ dengan resolusi grid $0,4 \AA$ pada kondisi ligan fleksibel. Dari nilai RMSD yang lebih kecil dari 2 maka dapat disimpulkan bahwa metode docking yang dilakukan valid sehingga dapat digunakan untuk docking senyawa 6,7-dihidro-17-hidroksierisotrin. 


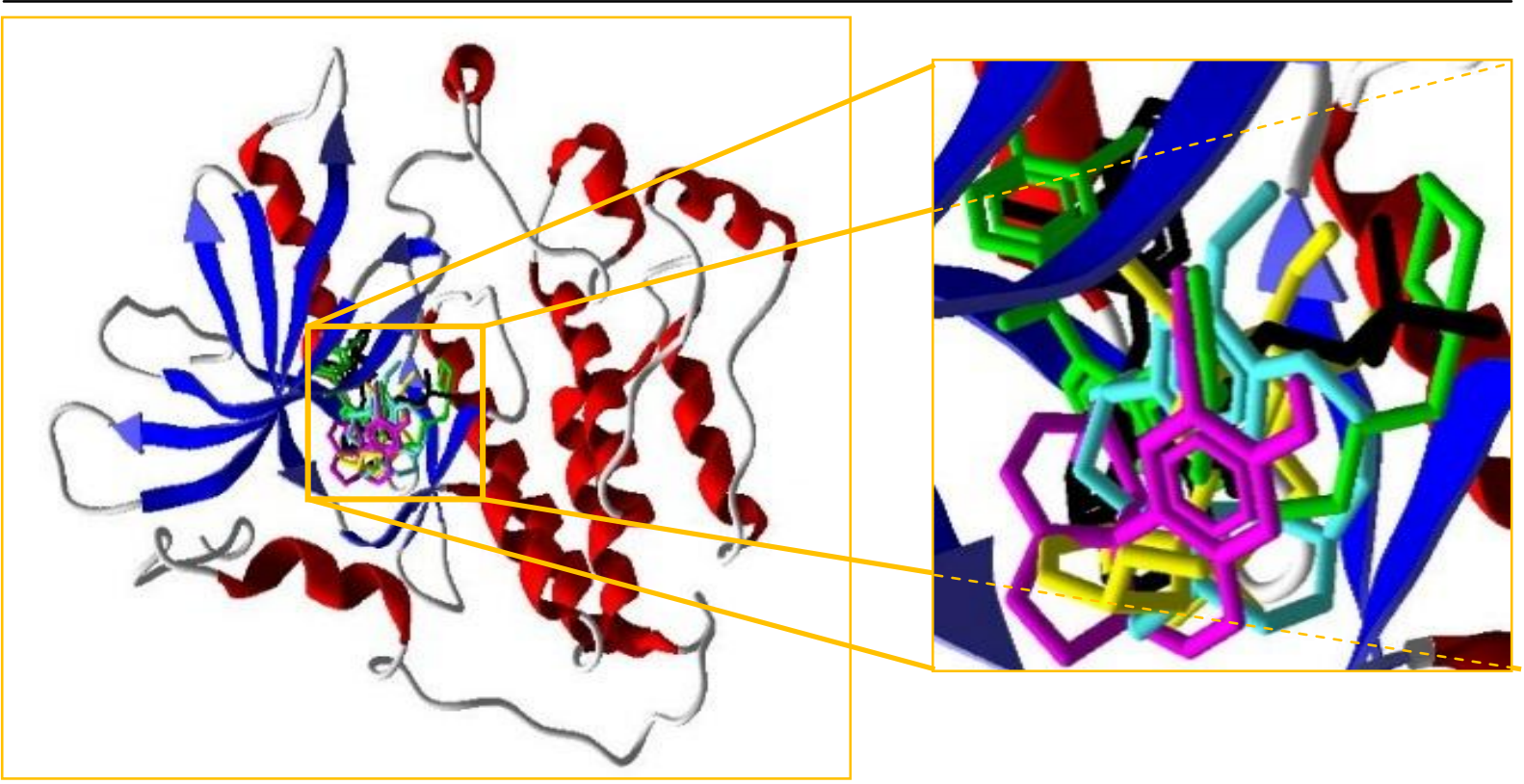

Gambar 2. Visualisasi interaksi 3D antara senyawa target (hitam), canertinib (hijau), senyawa 6,7-dihidro-17hidroksierisotrin (kuning) dengan reseptor EGFR 2

Hasil docking senyawa 6,7-dihidro-17hidroksierisotrin terhadap reseptor EGFR 2 dibandingkan dengan senyawa canertinib yang merupakan obat antikanker yang bekerja pada reseptor EGFR 2. Hasil docking berupa energi bebas Gibbs dan konstanta inhibisi dapat dilihat pada Tabel 1.

Tabel 1. Data energi bebas Gibbs ikatan dan konstanta inhibisi

\begin{tabular}{ccc}
\hline Senyawa & $\begin{array}{c}\Delta \mathrm{G} \\
(\mathrm{kcal} / \mathrm{mol})\end{array}$ & $\mathrm{Ki}(\mathrm{nM})$ \\
\hline $\begin{array}{c}\text { 6,7-dihidro-17- } \\
\text { hidroksierisotrin }\end{array}$ & $-8,11457$ & $1,12.10^{-6}$ \\
Canertinib & $-8,11505$ & $1,12.10^{-6}$ \\
\hline
\end{tabular}

Hasil docking pada Tabel 1 dapat dilihat bahwa ketiga senyawa 6,7-dihidro-17-hidroksierisotrin mempunyai energi bebas Gibbs ikatan $(\Delta \mathrm{G})$ hampir sama dengan senyawa pembanding (canertinib) sehingga ketiga senyawa 6,7-dihidro-17hidroksierisotrin dapat diprediksi mempunyai aktivitas yang sama seperti canertinib yaitu sebagai antikanker yang bekerjanya pada reseptor EGFR 2 . Semakin rendah nilai $\Delta \mathrm{G}$ yang dilepaskan pada saat interaksi senyawa dan reseptor maka ikatan kompleks senyawa dengan reseptor akan semakin kuat karena terjadi kestabilan dan kekuatan interaksi non-kovalen pada senyawa dengan reseptor, sehingga akan mudah masuk kedalam sel dan mengganggu replikasi DNA atau proses metabolisme akibatnya sel mati.

Energi bebas Gibbs ikatan $(\Delta G)$ berbandig lurus dengan nilai konstanta inhibisinya. Nilai konstanta inhibisi (Ki) juga memberikan gambaran afinitas antara senyawa dan penguraian. Semakin kecil nilai $\mathrm{Ki}$ maka kesetimbangan reaksi cenderung ke arah pembentukan kompleks senyawa-reseptor. Kompleks senyawa-reseptor dikatakan memiliki afinitas ikatan yang baik jika memiliki nilai $\mathrm{Ki}$ pada skala nanomolar dan dari hasil docking menunjukkan bahwa senyawa 6,7-dihidro-17-hidroksierisotrin memiliki estimasi nilai Ki pada skala nanomolar.

Hasil docking dapat dilihat juga visualisasi interaksi 3D antara semua senyawa dengan reseptor EGFR 2 seperti pada Gambar 2. Dari Gambar 2 dapat dilihat bahwa baik senyawa 6,7-dihidro-17hidroksierisotrin (kuning) dan pembanding canertinib (hijau) melalui proses docking akan berikatan di daerah senyawa target (hitam) yang diketahui mempunyai sifat sebagai penghambat EGFR 2.

\section{KESIMPULAN}

Dari isolasi daun Erythrina poeppigiana diperoleh senyawa alkaloid eritrina golongan isokuinolin dengan nama 6,7-dihidro-17hidroksierisotrin.

Dari hasil molecular docking dapat diprediksi bahwa Senyawa 6,7-dihidro-17-hidroksierisotrin mempunyai aktivitas sitotoksik terhadap sel kanker payudara MCF-7 dengan nilai $\Delta \mathrm{G}(\mathrm{Kcal} / \mathrm{mol})$ dan $\mathrm{Ki}(\mathrm{nM})$ sebesar $\left(-8,11457 ; 1,12.10^{-6}\right)$.

\section{Ucapan Terima Kasih}

Penulis mengucapkan terima kasih kepada Lembaga Pengelola Dana Pendidikan atas dana yang diberikan melalui Beasiswa Tesis dan Universitas Padjadjaran. 


\section{DAFTAR PUSTAKA}

Djiogue, S.M., Halabalaki, X., Alexi, D., Njamen, Z.T., Fomum, M.N., Alexis, A.L., \& Skaltsounis. 2014. Erythroidine alkaloid a new class of phytoestrogens. Planta Med. 80: 861869

Hanum, F., \& Maesen, L.J.G. 1987. Plant Resources of South-East Asia.PROSEA. Bogor.

Herlina, T., Herneti, D., Supratman, U., Subarnas, A., Supriatna., \& Hayashi H. 2003. A Paralytic
Alkaloid from Brak of Erythrina poeppigiana.

Mathematica et Natura Acta. 3. 6-5.

Kartasamita, R., \& Emran. 2009. Docking Turunan Kuersetin Berdasarkan Studi Interaksi Flavonoid Terhadap Enzim Siklooksigenase2. Indo. J. Chem: 9 (2). 297-302.

Purnomo, H. 2013. Kimia Komputasi Uji In Silico Senyawa Antikanker. Yogyakarta: Pustaka Pelajar. 